\title{
Awareness of Rural Producers Regarding the LR and PPA in Divinopolis, MG, Brazil
}

\author{
Nayara Bueno Porfírio ${ }^{1}$, Alysson Rodrigo Fonseca ${ }^{1}$, Ana Paula Fonseca ${ }^{1}$ \\ ${ }^{1}$ Universidade do Estado de Minas Gerais - UEMG, Divinópolis/MG, Brasil
}

\begin{abstract}
This study sought to evaluate the environmental awareness of small rural producers in the municipality of Divinópolis, MG, Brazil, regarding Legal Reserves - LR and Permanent Preservation Areas - PPA, referencing the state's current forest legislation, known as the Forest Code of Minas Gerais (Law 20.922/2013). For this purpose, a qualitative study was conducted using semi-structured interviews, with the sample defined by the saturation criterion, and issues considered using Bardin content analysis. The results showed that, in general, rural landowners define both evaluated terms incorrectly and/or incompletely. All of them reported not having knowledge of the environmental legislation and the majority declared not having been informed about the question and presented no record of LR notarization or registration at the Rural Environmental Registry - RER. This finding showed the need for the involvement of public and social institutions, and companies operating in the region to create guidance and training programs for landowners regarding environmental legislation, as well as encouraging the creation and maintenance of protected areas and supporting the environmental compliance of the properties.
\end{abstract}

Keywords: farmers, environmental legislation, Forest Code of Minas Gerais. 


\section{INTRODUCTION}

Rural producers are the most affected by forestry and biodiversity protection policy norms, given that the management of rural areas and properties, is normally exercised by the producer while managing the productive activities, be they agricultural, or in livestock, forestry, mining, aquiculture or even agroindustry (Mendes at al., 2012; Bedê, 2013).

Among the environmentally relevant areas in rural properties, the Permanent Preservation Areas - PPA and areas destined for Legal Reserve - LR are highlighted (Brasil, 2012). Although they bring social revenue and benefits, the legal existence of these areas has caused much controversy over recent decades, given that they are private and individual responsibilities for rural properties, representing a true administrative limitation on the right to property (Neumann \& Loch, 2002; Borges \& Rezende, 2011).

In general, in the case of the state of Minas Gerais (MG), Brazil, the rugged terrain and hydrographic abundance present a considerable limitation on land use for small rural properties in terms of economic exploitation (Rocha, 2009). However, although these areas are essential to sustain wild life and environmental dynamics, they are also considered sources of sustenance, when used for the production of food and other staple products derived from agricultural activities. In this context, rural producers would be the most interested parties in the adequate and rational functioning of this regulation, because they depend directly on the natural resources for their survival (Ribeiro \& Freitas, 2010; Bedê, 2013), showing the need for awareness and understanding regarding the use and function of environmental resources.

According to Fernandes et al. (2003), a reduction in environmental awareness, derived from a centenary culture of using natural resources without management strategies, is currently one of the greatest limitations to the changing concepts and paradigms. It also limits the application of environmental laws, regarding the preservation of areas that, in most cases, are considered economically productive by landowners. Thus, one of the difficulties for the protection of natural environments is in the existence of different perceptions of values and their importance among individuals from different socioeconomic contexts.
Rural landowners are the most affected by the decision to protect natural resources, and the need to characterize the farmer and the rural property due to the imposed legal requirements. Therefore, this study aimed to investigate the awareness of rural landowners from the municipality of Divinopolis, MG, about LR and PPAs, based on Laws 20.922/13 (Belo Horizonte, 2013) and 12.651 (Brasil, 2012). This was done to outline a local socio-environmental diagnosis that could assist in management projects and environmental education in the region.

\section{MATERIAL AND METHODS}

This qualitative-quantitative study seeks to analyze the awareness of small farmers regarding LR and PPAs, in two rural communities located in Divinopolis, MG. The municipality is located in the central-west region of Minas Gerais, Brazil, $106 \mathrm{~km}$ from the State capital, Belo Horizonte, having a territorial extension of $708.115 \mathrm{~km}^{2}$, and approximately 213,000 inhabitants (IBGE, 2010). The communities Córrego Falso and Quilombo were randomly selected from the ten largest communities in territorial extension and number of properties. Within them, all farmers with properties below 4 módulos fiscais were invited to partake in the study. From 23 properties, 18 accepted the invitation. The reference for small farmer was item IV, article 2, of the State Law n 20.922 of October $16^{\text {th }}, 2013$ (Belo Horizonte, 2013), which defines small properties as areas including between 1 and 4 módulos fiscais. According to the National Institute for Colonization and Agrarian Reform - INCRA, a modulo fiscal is an agrarian unit of measure used in Brazil and instituted by Law $n^{\circ} 6.746$ (Brasil, 1979), and is equivalent to 20 ha, in Divinopolis.

We obtained data by means of semi-structured interviews with a list of guided questions, and sought to characterize a few socioeconomic and environmental aspects of the properties, as well as the farmers' awareness regarding issues related to the PPAs and LR (Table 1). We also obtained information on gender, age, education level, marital status and number of children of each interviewee.

The answers were analyzed by means of the Content Analysis proposed by Bardin (2009). This methodology primarily consists of a set of communication analysis 
techniques, which seek to obtain indicators, by means of systematic and objective procedures to describe message content (quantitative or not), that allow the inference of knowledge concerning the production/reception conditions of these messages. It also seeks to discover the relations that exist between the exterior and the concept itself, involving deforestation and unit registration operations.

Because this is research that directly involves humans and, in accordance with the norms of the National Health Council Resolution $n^{\circ} 466$, of December 42012 , the project was sent to an Ethics Committee, duly registered with the National Commission for Ethics and Research - CONEP, and approved by the Consolidated Opinion CAAE: 31293114.0.0000.5115.

\section{RESULTS AND DISCUSSION}

The profile of the farmers interviewed in Divinopolis was outlined by basic traits such as gender, age, education level, marital status and number of children (Table 2). Among the 18 farmers interviewed, $61.11 \%(n=11)$

Table 1. List of questions applied to the interviewees (Divinopolis, MG).

Socio-economic and environmental aspects of the properties
What is the size of your property?
What types of cultivation/pasture are present on your property? What size are these areas?
Are there natural vegetation/forest areas on your property? If so, what size are they?
What types of animals are raised on your property?
Do you exercise any other economic activities on your property?
What water resources are present on your property?
What types of water supply are used on your property?
How do you dispose of waste generated on your property?
Questions related to the PPA's and LR
What do you understand by PPA and LR?
What importance do these areas have?
What is the preservation status of your property?
Regarding LR, is it registered or enrolled with the RER? If so, was there any difficulty to register or enroll it?
Have you received any guidance regarding environmental laws or property compliance?
What do you think of being required to recover and/or maintain the PPAs and LRs?
In your opinion, do environmental laws benefit or disadvantage farmers?

Table 2. Profile of interviewed farmers (Divinopolis, MG).

\begin{tabular}{cclcc}
\hline Gender & Age & \multicolumn{1}{c}{ Education Level } & Marital Status & Number of children \\
\hline M & 84 & Incomplete Elementary Schooling & Married & More than five \\
F & 49 & Higher Education & Single & None \\
M & 44 & Higher Education & Married & None \\
M & 40 & Incomplete Elementary Schooling & Married & Two \\
\hline F & 42 & Incomplete Elementary Schooling & Married & One \\
M & 46 & Incomplete Elementary Schooling & Married & One \\
F & 29 & Higher Education & Married & Two \\
F & 50 & Incomplete Secondary Education & Widower & Two \\
M & 56 & Complete High School & Single & None \\
F & 40 & Higher Education & Married & None \\
\hline M & 60 & Incomplete Elementary Schooling & Married & One \\
\hline M & 70 & Higher Education & Married & Two \\
\hline M & 31 & Complete Elementary Schooling & Married & One \\
\hline F & 45 & Complete Elementary Schooling & Married & Two \\
\hline M & 51 & Incomplete Elementary Schooling & Married & Two \\
\hline M & 48 & Complete Elementary Schooling & Married & Two \\
\hline F & 45 & Complete Elementary Schooling & & \\
\hline
\end{tabular}

$\mathrm{M}=$ male; $\mathrm{F}=$ female. 
of the individuals were male and $38.88 \%(n=7)$ were female. According to Costa \& Kato (2007), the predominance of the male gender in rural work is a result of agricultural activity being considered heavy. In most cases, women divide their time between household tasks and childcare, with little availability for field activities.

The interviewees were aged between 29 and 84 years, with only $11.11 \%(n=2)$ of the interviewees aged below 35 , which demonstrates that the studied population is adult. Concerning the education level, $38.88 \%(n=7)$ did not finish elementary school, $22.22 \%(\mathrm{n}=4)$ finished elementary school, 5.55\% $(\mathrm{n}=1)$ did not finish high school, $5.55 \%(\mathrm{n}=1)$ completed high school while only $27.77 \%(n=5)$ had higher education (Table 2$)$. According to Silva \& Mendes (2012), the low level of education found in Brazilian rural areas is mainly due to availability of schools, with exclusively multi-grade classes and literacy learning only up to the third year with rare exceptions. Therefore, if the student had the intention to continue their studies, they needed to migrate from rural to urban areas.

Regarding the marital status of farmers interviewed, $77.77 \%(\mathrm{n}=14)$ were married, $16.66 \%(\mathrm{n}=3)$ were single and $5.55 \%(n=1)$ were widowed. Concerning the number of children, $22.22 \%(n=4)$ had none, $27.77 \%(\mathrm{n}=5)$ had one child, 38.88\% ( $\mathrm{n}=7)$ had two children, $5.55 \%(\mathrm{n}=1)$ had three children and $5.55 \%(n=1)$ had more than five (Table 2). These results reflect the decreasing tendency of the size of Brazilian families, as a consequence of a decrease in the overall fertility rate. According to IBGE (2010), in 1970, on average Brazilian families had 5.3 individuals. In 1992, the size dropped to 3.7 individuals and, in 2010, it fell to 3.3 individuals.

\subsection{Aspects related to rural properties}

Regarding the rural properties, we surveyed information on the total area, cultivated area, pasture and natural/forest vegetation (Table 3 ) of the property. Improvement areas were not included, given that generally, landowners did not know their size and because they do not represent a significant part of the total area of the property. In this study, $27.77 \%(n=5)$ of the rural properties had a total area from 1 to 5 hectares, $22.22 \%(n=4)$ were sized from 6 to 10 ha; $27.77 \%(n=5)$ measured between 11 and 20 ha, 11.11\% $(n=2)$ had between 21 and 30 ha, and $11.11 \%(n=2)$ had between 31 and 68 ha.

Table 3. Characterization of the rural property areas (Divinopolis, MG).

\begin{tabular}{|c|c|c|c|c|}
\hline \multirow{2}{*}{ Properties } & \multicolumn{3}{|c|}{ Area (ha) } & \multirow{2}{*}{ Total } \\
\hline & Cultivars & Pasture & Natural/Forest & \\
\hline 1 & 1.5 & 12.5 & 3.0 & 17.0 \\
\hline 2 & 1.0 & 9 & 10.0 & 20.0 \\
\hline 3 & 15.0 & 6 & 7.0 & 28.0 \\
\hline 4 & 0.3 & 13.7 & 3.0 & 17.0 \\
\hline 5 & 10.0 & 13 & 5.0 & 28.0 \\
\hline 6 & 3.8 & 0 & 15.2 & 19.0 \\
\hline 7 & 5.8 & 0.4 & 1.1 & 7.3 \\
\hline 8 & 0.2 & 0 & 0.8 & 1.0 \\
\hline 9 & 2.0 & 37.7 & 1.0 & 40.7 \\
\hline 10 & 6.0 & 0 & 1.0 & 7.0 \\
\hline 11 & 4.0 & 0 & 2.0 & 6.0 \\
\hline 12 & 50.0 & 0 & 18.0 & 68.0 \\
\hline 13 & 1.5 & 0.5 & 0.0 & 2.0 \\
\hline 14 & 4.0 & 0 & 1.0 & 5.0 \\
\hline 15 & 0.33 & 2.37 & 0.0 & 2.7 \\
\hline 16 & 7.0 & 0 & 4.0 & 11.0 \\
\hline 17 & 4.0 & 0 & 2.0 & 6.0 \\
\hline 18 & 0.7 & 0.6 & 0.0 & 1.3 \\
\hline Mean & 6.5 & 95.7 & 4.1 & 15.9 \\
\hline
\end{tabular}


Regarding crops, $66.66 \%(n=12)$ of the properties presented between 0 and 4 ha, $22.22 \%(n=4)$ presented between 5 and 10 ha, and $11.12 \%(n=2)$ presented areas greater than 11 ha. As for pasture areas, $44.45 \%(n=8)$ of the properties presented no pasture, $33.34 \%(n=6)$ presented between 0 and 10 ha, $16.66 \%(n=3)$ presented between 10 and 20 ha, and only one property (5.55\%) presented a pasture area greater than 20 ha (Table 3 ).

When inquiring about cultivation types, most interviewees declared having greenery (Figure 1), which shows that this is one of the most important income and food sources for the landowner and their family. According to Silva (2013), temporary cultures, such as greeneries, act as an alternative mechanism between consumption and sale, which facilitates the adaptation of these productive units to the commercialization process. Additionally, as a subsistence activity, it favors the maintenance of a large population in rural areas.

Regarding natural/forest areas, $77.78 \%(n=14)$ of the properties presented between 0 and 5 ha, $11.11 \%(\mathrm{n}=2)$ presented between 6 and $10 \mathrm{ha}$, and $11.11 \%(n=2)$ presented areas larger than 11 ha (Table 3). These numbers indicate that most rural properties preserve natural forest areas. However, such areas are not proportional to the total area of the properties, given that the Forest Law of Minas Gerais (Belo Horizonte, 2013) determines that rural properties must maintain an area with native vegetation coverage as LRs (not counting PPAs), at a minimum percentage of $20 \%$ of the total property area. The PPAs might by computed into the calculation of the LR percentage of the area in some cases, according to art. 35 of the same law. Based on this, only $50 \%(n=9)$ of the rural properties involved in this research presented a sufficient proportion of natural/forest areas to compose the LR as established by the relevant environmental legislation. It is worth mentioning that, as there was no field evaluation, it was impossible to verify the successional and preservation condition of these areas.

Concerning livestock, 50\% ( $\mathrm{n}=9)$ of the rural properties responded that they raise dairy cattle, $22.22 \%(n=4)$ raise beef cattle, $5.56 \%(n=1)$ raise horses and $22.22 \%(n=4)$ have no livestock.

When asked about the existence of other economic activities in addition to rural production, $88.89 \%(n=16)$ of the interviewees answered having no other activity, $5.55 \%(\mathrm{n}=1)$ responded that they had income from rent and 5.55\% $(n=1)$ responded that they were a public servant. Therefore, the main income for most interviewees was from agricultural and livestock production. It is important to highlight that, especially for small producers and family farmers, the income obtained from activities in other economic sectors (multi-activity) is important to maintain the rural property and reflects directly on the well-being of the families.

In relation to the water resources on the property, $38.89 \%(n=7)$ of the interviewees answered that there is both a spring and a stream on the property, $16.66 \%(n=3)$ answered that there is a spring, $16.66 \%(n=3)$ answered that there is a stream, $5.56 \%(n=1)$ answered that there are three springs, $5.56 \%(\mathrm{n}=1)$ answered that there is a spring and a river, and $16.66 \%(n=3)$ answered that there were no water resources. This information shows that most rural properties have their own water sources, which reinforces the need to maintain and preserve the PPAs in these locations, in addition to the

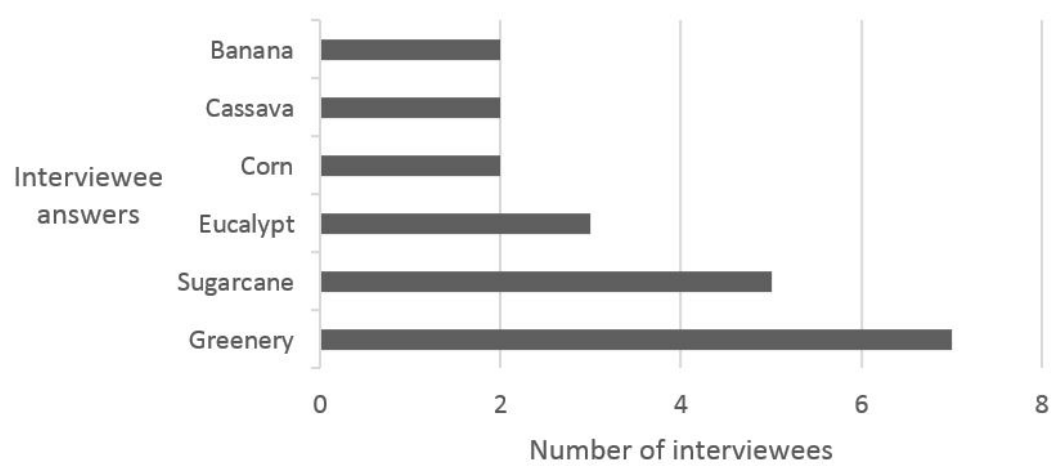

Figure 1. Crops identified on rural properties (Divinopolis, MG). 
LR area required by the Forest Code of Minas Gerais (Belo Horizonte, 2013).

Regarding water supply, $77.78 \%(\mathrm{n}=14)$ of the landowners reported using wells and $22.22 \%(n=4)$ used spring water. The high dependence on underground water, such as tube wells, is evidence of water scarcity, which has affected many Brazilian regions, including the central-west of Minas Gerais, with many farmers being forced to rely on this type of water source, after having their rivers and streams reduced or completely cut off by drought.

In relation to disposal of waste generated on the property, $50 \%(n=9)$ is collected by the city service, $27.78 \%(\mathrm{n}=5)$ is burnt, $11.12 \%(\mathrm{n}=2)$ is recycled, $5.55 \%(n=1)$ is buried, and 5.55\% $(n=1)$ had another destination. It is worth mentioning that, even though garbage trucks visit most rural communities at least once a week, the locations for depositing solid residues (for the truck to pick up) are inadequate, distant or insufficient for the volume generated. This situation leads to negative environmental outcomes on the rural properties, given that, when inadequately disposed of, these residues can contaminate soil and water, release foul odors and attract pathogenic organisms and/or disease vectors. They may also cause domestic or wild animals to ingest contaminated or toxic food.

\subsection{Aspects related to the knowledge of LRs and PPAs}

When asked what PPAs are, the most frequent answers were $38.89 \%(n=7)$ said that it is a forested area that should not be deforested, while $22.23 \%(n=4)$ responded that they are margins of streams and springs. The remaining frequent answers are presented in Figure 2.

In general, the awareness of landowners in terms of these areas does not correspond to the definition established by the environmental legislation, remaining partial and/or even incorrect, as can be observed in the statements below:

A forested area that no one "messes with"; a stream that no one can "mess" with the water (Interviewee 13, 31 year old).

A spring or stream area (Interviewee 16, 48 years old).

When questioned about the importance of the PPAs, all answers generally highlighted the environmental importance of these areas: $50 \%(n=9)$ stated that PPAs are important for water preservation. The remaining answers are presented in Figure 3. According to Borges \& Rezende (2011), one of the most important functions of PPAs is to preserve and conserve water, indicating that the responses show a certain degree of knowledge by landowners regarding this subject.

In relation to the conservation status of PPAs, the answers indicated that in $66.67 \%(n=12)$ of the properties they were preserved, and in $33.33 \%(n=6)$, they were partially preserved. It is worth mentioning that the answers obtained may not reflect reality, given that the landowners were still not able to present a clear definition of what a PPA is. The answers may also have been motivated by fear of disclosing any noncompliance on the property in terms of current environmental regulations.

When evaluating the awareness of the interviewees regarding what LRs are, $27.78 \%(\mathrm{n}=5)$ answered that

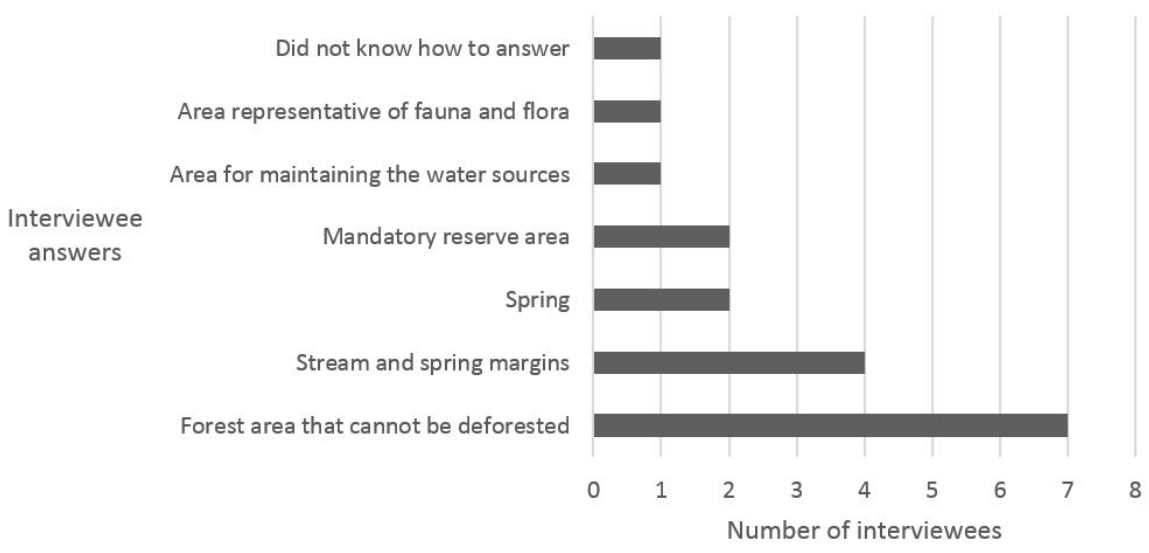

Figure 2. Most frequent answers obtained from the interviewees concerning the definition of PPAs. 


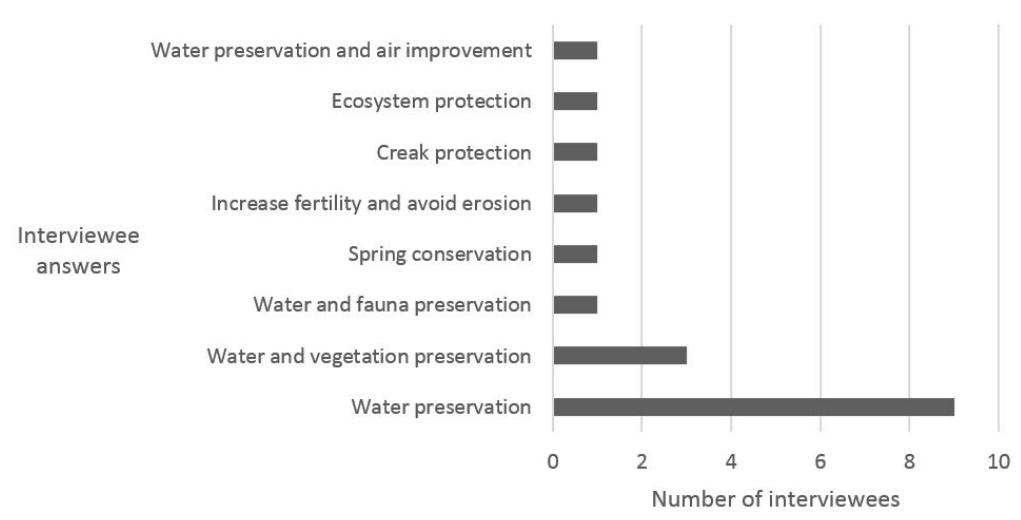

Figure 3. Most frequent answers obtained from the interviewees regarding the importance of PPAs.

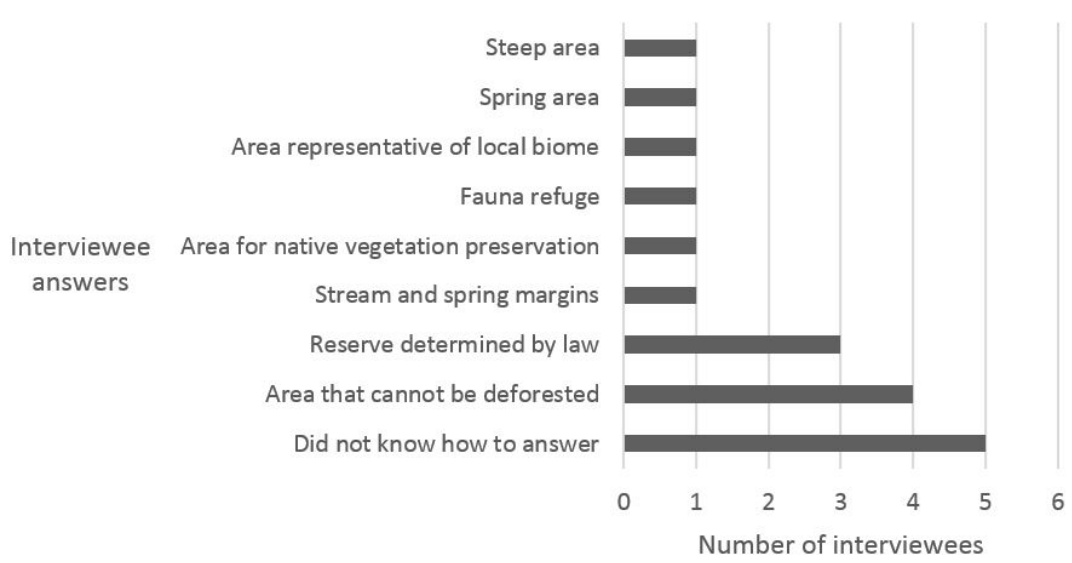

Figure 4. Most frequent answers obtained from the interviewees regarding the definition of LR.

they did not know what they are, $22.22 \%(\mathrm{n}=4)$ answered that they are an area that cannot be deforested, and $16.67 \%(n=3)$ answered that they are a protected area determined by law. The remaining response categories are presented in Figure 4. It is believed that the wide spread lack of understanding is due to a confusion between the concept of the terms considered in this research, that is, that the interviewees believe that PPAs and LRs refer to the same thing.

Based on the statements below, it is clear that the different answers given by the interviewees represent parts of the complete definition of the term LR, except for the answer "margins of streams and springs", since these terms are defined in the Forest Code of Minas Gerais as PPAs, which, in turn, can be considered as LRs in some cases. However, at no time was it possible to observe if the interviewees had knowledge regarding the possibilities of use of LRs, as determined by the new Forest Code (Brasil, 2012), as sustainable management for plant exploitation and harvesting of fruits, vines, leaves and seeds.

Area that cannot be deforested (Interviewee 10, 40 years of age).

Spring area (Interviewee 7, 29 years of age).

When asked if the landowners thought it important to maintain the LRs on their property, all of them ( $\mathrm{n}=18)$ answered yes, demonstrating that, despite the lack of knowledge of the term, they recognized the importance of maintaining these areas, and seemed to understand that this is a means of environmental preservation.

When asked if the properties presented LR registered at the notary or enrolled with the Rural Environmental Registry (RER), 77.77\% ( $\mathrm{n}=14$ ) answered yes, and $22.23 \%(\mathrm{n}=4)$ answered no. In this case, the interviewees who answered no were also those 
who declared not knowing what an LR was, showing a lack of guidance on the subject.

When inquiring about the difficulties found to register the LR (regarding the landowners who had already registered them in notary offices or enrolled them with RER), 35.71\% ( $\mathrm{n}=5)$ said that they had no difficulties. However, $21.43 \%(\mathrm{n}=3)$ pointed out the lack of information and guidance to register, $14.28 \%(\mathrm{n}=2)$ reported excessive bureaucracy, while $14.28 \%(\mathrm{n}=2)$, mentioned a lack of instruction and preparation of the public employees in this sector. In the case of landowners who had no registration at a notary offices or RER $(n=4), 50 \%(n=2)$ reported their intent to register their properties.

When questioned if they had had any instruction regarding environmental laws or property compliance, $77.77 \%$ ( $\mathrm{n}=14)$ stated that they had never been instructed, and only $22.23 \%(n=4)$ had been instructed more than two years prior, by the Technical Assistance and Rural Extension Company of the State of Minas Gerais - EMATER-MG, and by environmental consulting agencies. This lack of knowledge and guidance is clearly one the main reasons why environmental laws are not duly complied with, since individuals who depend on these natural resources for their work have no knowledge of the types of regulations applicable in the rural context.

Analyzing the answer categories related to what landowners know about their responsibilities to recover and/or maintain PPAs and LRs preserved on their properties, $38.89 \%(n=7)$ answered that it is important for water preservation, $16.66 \%(n=3)$ answered that if it were not mandatory, no one would conserve natural areas, $16.66 \%(n=3)$ answered that it is important to raise awareness regarding preservation, $11.12 \%(n=2)$ answered that it is good to create a tradition of conservation, $11.12 \%(n=2)$ answered that it is necessary to preserve the environment and $5.55 \%(n=1)$ answered that it is important to preserve habitats. One positive finding was that there were no positions contrary to the legal need to maintain or preserve these areas on the properties. The frequent relation between these preservation areas and water scarcity in the region was also noted:

The obligation to maintain these areas intact is a way to try to reverse the destruction of water sources and climate change (Interviewee 1, 84 years of age).
It's a good thing, because it helps conserve water (Interviewee 16, 48 years of age).

When questioned whether the environmental laws benefited farmers, $55.56 \%(\mathrm{n}=10)$ of the landowners stated that they hinder their work, $38.89 \%(n=7)$ declared that they were a benefit, and 5.55\% $(n=1)$ did not know how to answer. Among the answer patterns obtained for the non-benefit, $40 \%(n=4)$ stated that there was a decrease in the cultivation area on rural properties, $30 \%(n=3)$ said that there is no specific environmental law for the small farmer and $10 \%(\mathrm{n}=1)$, stated that there is no government incentive. The remaining percentages concern the statements below:

I think they are a disadvantage for us, because each individual has to preserve his own land, without receiving any government support for this (Interviewee 14, 45 years of age).

It is a disadvantage for us. Because the laws in Brazil are made to inspect and fine (Interviewee 9, 70 years of age).

Among the statements that indicated being favorable, $57.14 \%(n=4)$ stated that the existence of a law to preserve water is important:

It is important, so that water sources won't run dry (Interviewee 14, 45 years of age).

It benefits us, because otherwise, the water sources will run dry (Interviewee 16, 48 years of age).

It is interesting to observe that, even though farmers recognized the positive importance of preservation areas on their properties, most of them $(n=10)$ stated that the environmental laws are disadvantageous for farmers. We believe that a way to reverse this scenario would be to create mechanisms to make it easier for the registration, recovery and maintenance of these areas (where relevant), in addition to providing economic incentives, given that these protected areas provide a series of environmental services that benefit not only the ecosystem, but the entire society.

\section{CONCLUSIONS}

This research made it possible to analyze how the rural landowners in this study recognize the relation of their work with the environment, especially concerning their awareness of LR and PPA. In general, we found that, even though farmers recognize the importance 
of these preservation areas on their properties, they have no clear understanding of what they are, their aims or the difference between them. Farmers attribute this to a lack of guidance, bureaucracy and the costs of environmental compliance.

In order to create real awareness regarding the importance of preserving the environment and protected areas, it is necessary to make landowners perceive the co-responsibility they have with these areas on their properties, making them key stakeholders in this process. Therefore, society and local government should recognize the farmer as a guardian of this resource and give them the due financial assistance for the available products and environmental services rendered, given that most of the population located in urban areas depends on the natural resources and food taken from the field.

\section{SUBMISSION STATUS}

Received: 11 aug., 2016

Accepted: 20 aug., 2017

\section{CORRESPONDENCE TO}

\section{Alysson Rodrigo Fonseca}

Coordenações Integradas de Extensão, Pesquisa e Pós-graduação - CIEPP, Universidade do Estado de Minas Gerais - UEMG, Unidade Divinópolis, Av. Paraná, 3001, Jardim Belvedere, CEP 35501-170, Divinópolis, MG, Brasil e-mail: arodrigofonseca@hotmail.com

\section{REFERENCES}

Bardin L. Análise de conteúdo. Lisboa: Edições Setenta; 2009.

Bedê JC. Cartilha sobre a nova lei florestal de Minas Gerais: orientações aos produtores rurais. Belo Horizonte: Assembleia Legislativa do Estado de Minas Gerais; 2013.

Belo Horizonte. Governo do Estado de Minas Gerais. Lei $n^{\circ} 20.922$, de 16 de outubro de 2013. Diário do Executivo, Belo Horizonte, MG. (2013 out.).
Borges LAC, Rezende JLP. Áreas protegidas no interior de propriedades rurais: a questão das APP e RL. Floresta e Ambiente 2011; 18(2): 210-222. http://dx.doi.org/10.4322/ floram.2011.040.

Brasil. Casa Civil. Lei nº 6.746, de 10 de dezembro 1979. Diário Oficial da República Federativa do Brasil, Brasília, DF (1979 dez.).

Brasil. Casa Civil. Lei Federal no 12.651, de 25 de maio de 2012. Diário Oficial da República Federativa do Brasil, Brasília, DF (2012 maio).

Costa MS, Kato MS. Trabalho de Homem, Trabalho de Mulher: divisão social de trabalho em cinco localidades agrícolas do nordeste do Pará. Revista Brasileira de Agroecologia 2007; 2(1): 832-836.

Fernandes RS, Souza VJ, Pelissari VB, Fernandes ST. Uso da percepção ambiental como instrumento de gestão em aplicações ligadas às áreas educacional, social e ambiental demográfico [online]. São Paulo: Escola Superior de Agricultura Luiz de Queiroz; 2003. [cited 2015 Apr 8]. Available from: http://www.redeceas.esalq.usp.br/noticias/ Percepcao_Ambiental

Instituto Brasileiro De Geografia e Estatística - IBGE. Censo demográfico [online]. Rio de Janeiro: Diretoria de Pesquisas; 2010. [cited 2015 Dec 5]. Available from: http:// cidades.ibge.gov.br/xtras/perfil.php?lang=\&codmun=312230 Mendes CJ, Neves CU, Berger R. Áreas de preservação permanente e reserva legal: percepção dos proprietários rurais do município de Otacílio Costa, SC. Floresta 2012; 42(4): 671-682. http://dx.doi.org/10.5380/rf.v42i4.17283.

Neumann PS, Loch C. Legislação ambiental, desenvolvimento rural e práticas agrícolas. Ciência Rural 2002; 32(2): 243 249. http://dx.doi.org/10.1590/S0103-84782002000200010.

Ribeiro KT, Freitas L. Impactos potenciais das alterações no Código Florestal sobre a vegetação de campos rupestres e campos de altitude. Biota Neotropica 2010; 10(4): 239-246. http://dx.doi.org/10.1590/S1676-06032010000400029.

Rocha RRC. Análise das limitações do Direito na solução de conflitos ambientais: a aplicação de sistemas de informações geográficas a processos judiciais [dissertação]. Viçosa: Universidade Federal de Viçosa; 2009.

Silva JM, Mendes EPP. Desafios dos agricultores familiares nas comunidades rurais Cruzeiros dos Martírios e Paulistas, Catalão (GO). Revista Formação Online 2012; 19(2): 32-50.

Silva RN. Pluriatividade na agricultura familiar tradicional do Estado de Mato Grosso [dissertação]. Campo Grande: Universidade Católica Dom Bosco; 2013. 